\title{
THE EU-JAPAN STRATEGIC PARTNERSHIP AGREEMENT (SPA) - REALLY MORE POLITICAL AND SECURITY COOPERATION ON THE GROUND?
}

\author{
AXEL BERKOFSKY (*) \\ Nota presentata dal m.e. Silvio Beretta \\ (Adunanza del 15 novembre 2018)
}

\begin{abstract}
SunTO. - Nel luglio 2018 il Giappone e l'Unione Europea hanno adottato l'accordo EU-Japan Strategic Partnership (SPA). L'accordo si propone di istituzionalizzare ulteriormente la cooperazione UE-Giappone nel campo della politica e della sicurezza regionale e internazionale. Stando alla retorica politica che ha accompagnato l'adozione dell'accordo, si potrebbe essere tentati di concludere che questo rappresenti la svolta attesa nella cooperazione politica e di sicurezza UE-Giappone per gli anni a venire. Purtroppo le cose non stanno così, almeno non ancora. Nell'accordo l'UE e il Giappone prevedono infatti di cooperare in oltre 40 settori fra i quali: proliferazione delle armi di distruzione di massa, gestione delle crisi, ricostruzione postbellica, prevenzione della proliferazione di armi convenzionali comprese le armi leggere e di piccolo calibro, politiche antiterrorismo, riforma delle Nazioni Unite, politiche di sviluppo, gestione delle catastrofi, cambiamenti climatici e molte altre questioni sono entrate nel lungo elenco dei problemi irrisolti. La buona notizia è che la SPA copre un numero inferiore di questioni rispetto al precedente accordo, lo EU-Japan Joint Action Plan 2001-2011, che riguardava oltre 100 campi di collaborazione. La nuova SPA, comunque, comprende ancora più di 40 aree e, sfortunatamente, non sono disponibili informazioni che specifichino l'ordine di priorità: ed è probabile che, quando le priorità non vengono indicate, i risultati pratici finiscano con l'essere scarsi, almeno fino a quando non vi sia accordo anche sulle precedenze da perseguire.
\end{abstract}

(*) Università degli Studi di Pavia, Dipartimento di Studi Politici e Sociali, Pavia, Italia. E-mail: Axel.Berkofsky@unipv.it 
ABSTRACT. - In July 2018, Japan and the European Union adopted the bilateral Strategic Partnership Agreement (SPA). The SPA is aimed at further institutionalizing EU-Japan cooperation in regional and international politics and security. Based on the political rhetoric accompanying the agreement's adoption, one could be tempted to conclude that the SPA will be the long-awaited breakthrough of EU-Japan political and security cooperation in the years ahead. But it is not, at least not yet. In the agreement, the EU and Japan envision cooperation in more than 40 areas. You name it, it is all in the agreement: cooperation countering the proliferation of weapons of mass destruction, crisis management, post-conflict reconstruction, collaboration to prevent the proliferation of conventional arms, including small arms and light weapons, joint counter-terrorism policies, joint efforts to reform the UN, development policies, disaster management, climate change and many, many other areas and issues made it onto that very long list of unresolved issues of international politics and security. The good news is that the SPA covers fewer issues and areas than the previous EU-Japan Action (2001-2011), which covered more than 100 areas the EU and Japan were at the time planning to cooperate on, and - with a few notable exceptions - did not. The not so good news is that the new SPA still covers more than 40 areas and there is unfortunately no information publicly available outlining which areas and/or issues have priority over others. Reality (most probably) is that when one does not prioritize anything, then not much will get done unless and until there is agreement between the EU and Japan on what needs to be done first, second and third.

\section{INTRODUCTION}

The European Union (EU) and Japan have over recent years intensified ad-hoc cooperation in various fields of international politics and security. Indeed, the track record of the EU and Japan initiating and adopting joint policies on both a regional and global scale is promising, and includes various joint missions, conflict mediation and peace-building initiatives in Africa and Asia. However, EU-Japan non-combat military-tomilitary cooperation (in Asia particular) has yet to reach its full potential and the EU-Japan Strategic Partnership Agreement (SPA) currently negotiated by the EU and Japan is aimed at further intensifying and institutionalising European-Japanese security cooperation on the ground. During the $24^{\text {th }}$ EU-Japan Summit in July 2017, the EU and Japan announced to have reached an 'agreement in principle' on the SPA and all of its 54 articles, including the ones which were until then were referred to as 'politically sensitive.' The EU and Japan have - at least on paper - ambitious plans regarding cooperation in international politics and security. The instrument and agreement through which such increased and institutionalized cooperation is envisioned to take place is the so-called Strategic Partnership Agreement (SPA). The SPA covers EU-Japan cooperation in regional and global politics and security and is planned to give the current 
EU-Japan ad-hoc security cooperation in various parts of the world an institutional framework. The adoption of the SPA, however, is not necessarily a precondition for Brussels and Tokyo to get engaged in on the ground cooperation in regional and global politics and security. Brussels and Tokyo have over the years signed a number of important agreements and protocols in the areas of non-proliferation, disarmament, human rights, Asian security etc. To be sure, signing agreements and protocols is not the same as adopting joint policies on the ground and the EU-Japan SPA is therefore also aimed at following-up on previously signed agreements and protocols with further joint policies. When EU-Japan negotiations were launched in 2013, the EU was able to convince Japan that the EPA and SPA would not be adopted separately but simultaneously as a 'package'. Convincing Japan required some negotiations and EU insistence, according to what the author was told by EU policymakers involved in the negotiations, as from the onset Japan was more interested in the EPA than a SPA, not least as a counter to the free trade agreement the EU adopted with South Korea in October 2015. Japanese companies (carmakers in particular) were concerned about loosing market share to South Korean counterparts The simultaneous adoption of both agreements, however, did not take place in the end: while the EPA/FTA was adopted on December 8, 2017, the SPA was adopted six months later (in July 2018). While the EU Commission's Directorate-General for Trade (DG Trade) in July 2017 decided to make the EPA draft agreement publicly available in mid-2017, the EEAS did not follow suit. The decision not to make information public gives the impression that EU policymakers think they are operating in an area where transparency and accountability are optional as opposed to compulsory. Or, possibly, the EU Commission, which is in charge of the EU-Japan Economic Partnership Agreement (EPA)/Free Trade Agreement (FTA), took the step to counter accusations of non-transparency while the EEAS chose to ignore these accusations. The adoption of the SPA has been accompanied by the establishment of an EU Commission-EEAS EU-Japan joint committee, i.e. a committee through which the EU Commission informs the EU's European External Action Service (EEAS) on the state and progress of the more than $40 \mathrm{EU}$ Japan sectoral dialogues. So far, there are no regular exchanges between the EU Commission and the EEAS on EU-Japan sectoral dialogues, a result undoubtedly of the traditional rivalry and struggle over competencies between the EU Commission and the EEAS. Either way, a joint EUJapan committee could be an effective instrument for the EU Commission 
and the EEAS to inform each other on respective policies towards Japan.

What certainly came as a disappointment to those who hoped that Japan would also want to get more involved in an institutionalized manner in European Common Security and Defence Missions (CSDP), Brussels and Tokyo were not able to make any progress towards the adoption of the so-called Framework Partnership Agreement (FPA). The FPA would create the legal framework to enable the deployment of Japanese armed forces within the framework of CSDP missions. The FPA would institutionalize already ongoing Japanese contributions to CSDP missions as the EU and Japan are currently in legal terms not conducting joint security and defence missions, but are engaged in what Brussels refers to 'parallel coordinated action.' FPA negotiations, however, this author learned from EU sources, have over the last two years gone nowhere as Japan is reportedly not nearly enough interested in the agreement to adopt it in a timely fashion. The original plan was to adopt the FPA together with the SPA. Japan's relative disinterest in the FPA goes in accordance with Tokyo's recent disengagement from international politics and security. Japan does currently not have any UN peacekeepers contributing to global UN peacekeeping missions and Japan's enthusiasm for more involvement in global security has decreased in recent years. Indeed, Tokyo under Prime Minister Abe is clearly more interested in - his critics would say 'obsessed with' - revising the country's pacifist country to allegedly make a 'normal' and 'fully independent' country out of Japan. That objective is accompanied by Tokyo seeking to further expand its hard military security ties with some European countries such as e.g. France, the UK and also Germany. Since Japan abolished its self-imposed ban to export weapons and weapons technology in 2013, defence contractors from France, the UK and Japan have established closer ties, which are accompanied by joint development of military and defence equipment.

Against the background of the global crisis of liberalism, the adoption of the SPA already in 2017 would have sent an important message that the EU and Tokyo are serious about joining forces to uphold and defend established standards of international politics and security. While the US under President Donald Trump has sometimes turned to isolationist foreign policies and protectionist trade policies (referred to as 'America First Policies' by Trump), China is, in defiance of liberal 
norms - as we have seen when China dismissed the July 2016 verdict of the Permanent Court of Arbitration in The Hague which ruled that China cannot claim historical territorial rights in the South China Sea. ${ }^{1}$ Against the background of China's global challenge to liberal values, Brussels and Tokyo's failure to meet their deadline to conclude an SPA arguably displays a lack of commitment to defend liberal values and thwarting the challenge posed by China.

\section{YEARS OF NEGOTIATIONS}

During the 20 $0^{\text {th }}$ EU-Japan Summit in 2010 Brussels and Tokyo agreed to adopt two legally-binding agreements: one to institutionalize and expand bilateral cooperation in international political and security and another to increase bilateral trade and investment ties through a free trade agreement. $^{2}$ Initially in 2010 the two sides launched the so-called Framework Agreement (FA) (which was later re-named into Strategic Partnership Agreement (SPA) and the EU-Japan Economic Partnership Agreement (EPA)/Free Trade Agreement (FTA)/Economic Partnership Agreement (EPA). A year later, so-called 'scoping exercises' were launched after the EU-Japan 2011 summit for both agreements, as part of a parallel negotiation process. 'Parallel' in the sense that it was agreed at the time that the two agreements would be adopted together. At that time the European Commission sought the necessary authorization from the Union's member states for negotiating these agreements based on a successful outcome of the 'scoping exercises." The 'scoping exercises' were launched as part of a preparatory phase, during which both the EU and Japan sides committed

1 Permanent Court of Arbitration (PCA (2016). PCA Press Release: The South China Sea Arbitration (The Republic of the Philippines v. The People's Republic of China, July 12, 2016; https://pca-cpa.org/en/news/pca-press-release-the-south-china-seaarbitration-the-republic-of-the-philippines-v-the-peoples-republic-of-china/.

2 See R. Tyszkiewicz, Towards New Political and Economic Agreements with Japan: Bringing New Dynamism into the Strategic Partnership between the EU and Japan. Policy Paper No. 9 (57) 2013, The Polish Institute of International Affairs (PISM) Warsaw, Poland; https://www.pism.pl/files/?id_plik=13357.

3 C. Prado De, Prospects for the EU-Japan Strategic Partnership. A Global Multi-Level and Swop Analysis; European University Institute Global Governance Programme 2014; https://www.eu-japan.eu/sites/default/files/publications/docs/eujpstrategicpartnership.pdf. 
themselves to agree on a common platform from which to negotiate both agreements. For the EU, the 'scoping exercises', i.e. regular bilateral working-level encounters, had to result in Japan declaring itself prepared to negotiate to remove all trade barriers - from procurement and investment barriers to tariffs and most importantly the numerous Japanese non-tariff barriers when trading with Brussels. The scoping exercises for the SPA and FTA were successfully concluded in April and May 2012 respectively. EUJapan Strategic Partnership Agreement (SPA) negotiations were launched in 2013, and after the $11^{\text {th }}$ round of negotiations in March 2016, the EU and Japan were able to agree on 31 out of 54 articles in the agreement. The outstanding articles - referred to by the EU as 'politically sensitive' were, as mentioned above, agreed upon in July 2017. The SPA is envisioned to be 'binding' in the sense that it consists of - at least according to EU sources - a well-defined list of issues and areas the EU and Japan will be dealing with in the years ahead. Compared to the previous EU-Japan Action Plan (adopted in 2001 and expired in 2011), the SPA will not be limited by a specific timeframe. The SPA will cover bilateral cooperation in politics and security and it will define arrangements for regular meetings between political leaders and ministry officials. The SPA is covering cooperation in over 40 areas and its adoption results in an upgrade in EU-Japan relations, moving from sectoral agreements to a comprehensive, binding and forward-looking framework.

\section{WHAT KIND OF AGREEMENT?}

Tokyo was always opposed to the introduction of the so-called 'Essential Elements Clause' into the agreement, a clause through which the EU would reserve the right to link issues such as human rights and non-proliferation of weapons of mass destruction to trade agreements it adopts with other countries, interrupting those agreements when violations occur. Even if the clause is reciprocal, i.e. even if Japan too has the right to interrupt a free trade agreement in response to human rights violations and the proliferation of weapons of mass destruction by the EU, Tokyo has nonetheless been opposed to including that clause. EU sources tell this author that the EEAS is not 'happy' about having to insert that clause into an agreement with a democratic country. That clause, EU sources emphasise, has been 'imposed' on Brussels by EU member states, and if it were not for EU member states' insistence to 
insert that clause, it would not be in the agreement with democratic Japan. EU sources tell this author that while individual EU member states do not have 'essential elements' clauses in their bilateral agreements with other countries, they expect the EU to have such clauses in its agreements. The treaty-based requirement for the EU to conduct a principled foreign policy is formulated in Article 21 of the Treaty of the Functioning of the European Union (TFEU). This requires the EU to stipulate in all agreements the commitment for the respect and protection of human rights and the non-proliferation of weapons of mass destruction, as well as find a mechanism to link these political principles to the EU's trading concessions. This concerns not only Japan but also other like-minded and strategic partners such as South Korea, Canada, Australia, New Zealand. While this linkage may be a legal requirement for the EU, it has been contested by some of the EU's partners, including Japan. The legal link was approved by the Union's Committee of Permanent Representatives (COREPER) in 2009, through which the EU authorizes itself to suspend a free trade agreement in case of e.g. human rights violations committed by the other party of the agreement. To be sure, that is highly unlikely in the case of Japan, but a from a Japanese perspective such a clause is without a doubt unwelcome as it - from a Japanese point of view - conveys a message of Brussels 'supervising' the quality of Japanese foreign and domestic policies. ${ }^{4} \mathrm{Japan}$, however, had to swallow that bitter pill and accept the 'essential elements' clause.

\section{THE FRAMEWORK PARTNERSHIP AGREEMENT (FPA)}

In addition to the EPA and SPA, Brussels and Tokyo are currently negotiating the Framework Partnership Agreement (FPA), an agreement aimed at facilitating the deployment of Japanese armed forces within the framework of European Common Security Defence Policy (CSDP) mission. ${ }^{5}$ The FPA would institutionalise already ongoing

4 M. Reiterer, The EU-Japan Relationship in Dynamic Asia' in Joern Keck/Dimitri Vanoverbeke/Franz Waldenberger (eds.) From Confrontation to Global Partnership. EU-Japan Relations from 1970 to the Treaty of Lisbon and Beyond. London: Routledge 2013, 293-328.

5 European External Action Service (EEAS) (2016 July 8), Shaping of a 
Japanese contributions to CSDP missions. However, there is no information publicly available on the current state of negotiations other than that they are 'ongoing.' Without the FPA, the EU and Japan are strictly and legally speaking not conducting a joint mission, but are engaged in what Brussels refers to 'parallel coordinated action.' The FPA, as the analyst Andrea Fontini argues, is aimed at creating synergies between the EU's 'comprehensive approach' to security and Japan's 'human security' concept in the Middle East and Asia. ${ }^{6}$ However, there are no clear indications as to how and to what extent Brussels' 'comprehensive approach' and Tokyo's 'human security' concept are compatible. Indeed, arguing that they could be compatible leading to joint EUJapan policies applying both approaches of security on the ground (in the Middle East, Africa or Asia) is little more than speculation and guesswork in the absence of empirical evidence. It remains to be seen in both Brussels and Tokyo whether the EU and Japan can coordinate and harmonize the way they operate on the ground. Is Japan prepared to put its armed forces under European command, authorizing its solders to apply EU Rules of Engagement in case they come under attack? Fontini also refers to what he calls 'post-industrial security dossiers' such as counter-terrorism, maritime security, resource management (among others water, food and energy), natural disaster prevention and management, cyber-defence, arms control, non-proliferation of weapons of mass destruction and others as areas where the EU and Japan cooperate.

\section{THE TRUMP FACTOR}

Against the background of EU-Japan joint rhetoric, which numerous times in the past suggested that Brussels and Tokyo are 'natural allies' sharing the same values and approaches to international politics and security, EU-Japan preparedness to increase security

Common Security and Defence Policy; https://eeas.europa.eu/headquarters/headquarters-homepage/5388/shaping-common-security-and-defence-policy_en.

6 A. Fontini, Advancing the EU-Japan Strategic Partnership in a Transforming Global Environment: Challenges, Opportunities and Prospects. European Policy Centre (EPC) Policy Brief 2016; http://www.epc.eu/documents/uploads/pub_6363_eujapan_strategic_partnership.pdf. 
cooperation should have received a boost with the election of Donald Trump as U.S. President. Perhaps it indeed did in the second half of 2017, when SPA negotiations accelerated, leading to the above-mentioned 'agreement in principle' on the SPA. Abe's EU policy advisors must have advised the Prime Minister not only to invest resources into the alliance with the U.S. under an unpredictable president, but also to make good on the promise to jointly contribute to regional and global stability with fellow 'soft power' EU during turbulent times. To be sure, the Japanese Prime Minister throughout 2017 did not fail to display the sort of strong interest, and even awkward and sometimes obsessive enthusiasm, to stay on Trump's good side; an enthusiasm Abe first displayed when Trump won the U.S. presidential elections. Indeed, after Trump's victory Abe did not loose much time to 'present' himself to the President-elect, travelling to New York in midNovember 2016 for a meeting. Abe, it seemed, was above all interested in making sure that the terms and quality of Tokyo's security alliance with Washington under remain unchanged, and that Trump would not after his inauguration act on what he said during the election campaign regarding U.S.-Japan relations. Without offering any details whatsoever, at the time Trump announced that as President he would deal with what he referred to as Japan's 'unfair trade practices'. Furthermore, Trump announced that he would oblige Tokyo to contribute 'more' to Asian security in general, and to the stationing of U.S. military troops on Japanese soil in particular. ${ }^{7}$ None of this as it turned out made it onto the official agenda of the first Abe-Trump summit. Against that background and in view of Shinzo Abe's apparently very strong interest to not in any way rock the boat of U.S.-Japan relations it seems rather unlikely that Tokyo will invest significantly more resources into expanding security cooperation with the EU after the adoption of the SPA. In other words, Prime Minister Abe is arguably the 'wrong' Prime Minister to take European-Japanese security cooperation to the 'next level' as EU and Japanese policymakers have often talked about in the past. Abe's his foreign and security policies priorities and his ambitions to expand Japan's role and com-

7 H. Ueno, M. Rich, Across the World, Shock and Uncertainty at Trump's Victory; New York Times November 9, 2016; https://www.nytimes.com/2016/ 11/09/world/europe/global-reaction-us-presidential-election-donald-trump.html. 
petencies in the framework of Tokyo's bilateral military alliance with the U.S. point to the conclusion that Abe is much more interested in expanding Japan's territorial defence profile and positioning as opposed to invest more resources into expanding non-military security cooperation with the EU.

\section{5. 'REAL' SECURITY COOPERATION TOO?}

EU-Japan military-to-military security cooperation dates back to the year 2009, and joint EU-Japan counter-piracy operations in the Gulf of Aden off the coast of Somalia. Japanese Maritime Self-Defense Force (MSDF) destroyers participated since March 2009, along with two P-3C maritime patrol aircraft added in June 2009. The MSDF unit has been providing information to other countries and has been conducting operations in the field, including with the EU Naval Force (NAVFOR) Somalia-Operation Atalanta, a CSDP military mission operational since the end of 2009. On January 18, 2014 e.g., Japan-EU cooperation led to the capture of pirates when a helicopter from the MSDF destroyer Samidare and a P-3C patrol aircraft detected a suspicious vessel and provided this information to the Combined Task Force 151 headquarters. In response, a helicopter from a French EU NAVFOR naval vessel was dispatched, which led to the capture of five pirates and the release of the vessel's crew. Japan and Europe have been conducting joint counter-piracy exercises since October 2014. In October and November 2014, MDSF destroyer Takanami participated in exercises with Italian, German, and Dutch naval vessels. These consisted of operations such as communications, tactical manoeuvring, helicopter take-off and landing and boarding. Japan's MSDF and EU NAVFOR have, since 2010, exchanged information on numerous occasions. However, to refer to EU-Japan information sharing as a 'joint EU-Japan mission' (as the EU and Tokyo have repeatedly done) is probably a bit of a stretch as this data sharing takes place in the framework of a multinational and UN-sanctioned mission combating piracy off the coast of Somalia. That said, however, it should not go unmentioned that Japanese navy vessels have escort commercial vessels through the Gulf of Aden in coordination with EU NAVFOR, which is in charge of managing the escorts. Furthermore, the EU and Tokyo are also providing development assistance to Somalia and some neighbouring countries, and are jointly helping to train Somali maritime security 
officials. Japanese scholar Akiko Fukushima argues that there is further potential for collaboration. ${ }^{8}$

\section{TOKYO CONTRIBUTING TO COMMON SECURITY AND DEFENCE POLICY (CSDP) MISSION?}

In August 2012, the EU deployed a civilian CSDP mission to provide training and advice to Niger's security sector. In December 2014, Tokyo decided to provide grant aid through the UN Development Program to the EU's CSDP mission in Niger. In that context Japan is contributing $¥ 202$ million for wireless communication devices to connect regional government offices with bureaus under their jurisdiction, as well as wireless-equipped vehicles for patrolling in various locations in Niger's seven administrative regions. In April 2014, the EU dispatched a civilian CSDP mission aimed at improving Mali's security capabilities. A year later in March 2015, Japan started contributing to that mission, providing grant aid amounting to $¥ 492$ million for the rehabilitation of Mali's national police school. Japan's cooperation with CSDP missions, Fukushima argues, was facilitated by the expertise Tokyo gained through rebuilding infrastructure in Iraq since the early 2000s (for which Japan used part of its Official Development Assistance (ODA) budget).

During the 22 $2^{\text {nd }}$ Japan-EU Summit in Brussels in May 2014, Prime Minister Abe, then President of the European Council Herman Van Rompuy, and President of the European Commission Jose Manuel Barroso, announced the goal of institutionalizing collaboration between the EU's CSDP missions and Japan's assistance and security cooperation initiatives in direct support of ongoing CSDP missions. At the time Brussels and Tokyo also expressed their commitment to ensuring strict export control of arms and dual-use technologies, especially to conflict zones. Finally, Brussels and Tokyo announced plans to fur-

8 A. Fukushima, Japan-Europe Cooperation for Peace and Stability: Pursuing Synergies on a Comprehensive Approach. Policy Brief Asia Program April 2015. The German Marshall Fund of the United States 2015; http://www.gmfus.org/publications/ japan-europe-cooperation-peace-and-stability. 
ther intensify collaboration between Tokyo's humanitarian and technical assistance operations and the EU's CSDP mission in Mali and the Democratic Republic of Congo. They e.g. agreed to strengthen joint capacity building measures of the national military forces of Mali, to jointly support the peacekeeping school of Bamako, jointly assist the improvement of security, antiterrorism laws and enhancement of judicial cooperation in Mali. It was also agreed to jointly assist capacity building measures of police officers and judicial administrators in the Democratic Republic of Congo. Finally, it was agreed to jointly assist the improvement of security, antiterrorism laws and enhancement of judicial cooperation in Niger.' Japan applies its so-called 'comprehensive approach' to development cooperation under its new Development Cooperation Chartera long with Tokyo's new security legislation adopted in 2015, which has potentially opened additional opportunities for security cooperation with the EU.

\section{Defence ties with Paris AND LONDON}

In January 2014, France and Japan held their first ministerial-level foreign affairs/defence ministers ( 2 plus 2 ) meeting. During the second 2 plus 2 meeting in 2015, respective foreign and defence ministers discussed the so-called 'Plan of Action for Africa', which included the possibility of joint border security actions in Niger, Mali and Burkina Faso, and joint peacekeeping policies and missions in Africa. In July 2014, Paris and Tokyo signed a Memorandum of Understanding (MOE) to increase defence cooperation, including the joint development of military equipment. This includes joint development of unmanned underwater vehicles.

In April 2012, Tokyo and London signed a first joint weapons development agreement, which in July 2013 was followed-up by two additional British-Japanese agreements - the so-called 'Defence Equipment Cooperation Framework' to facilitate joint development of

9 European Commission, The EU and Japan Acting Together for Global Peace and Prosperity; European Commission 22 ${ }^{\text {nd }}$ EU-Japan Summit Joint Press Statement May 7, 2014; http://europa.eu/rapid/press-release_STATEMENT-14-151_en.htm. 
military equipment and the 'Information Security Agreement', which aims to facilitate increased intelligence cooperation. This resulted, in among others, British-Japanese joint development of chemical and biological warfare suits, and cooperation in missile technology. Furthermore, British and Japanese armed forces at the time began conducting joint military exercises, and Tokyo and London held their first 2 plus 2 plus minister's meeting in January 2015. In May 2014, London and Tokyo initiated negotiations on a bilateral Acquisition and Cross-Servicing Agreement (ACSA), which facilitates the provision of logistical, material, ammunition and technical support for each other's armed forces.

\section{THE CHINA FACTOR}

China's military rise and its increasingly assertive regional security policies in general, and policies related to maritime territorial claims in the East and Southeast Asia in particular, could have been an incentive to intensify EU-Japan security cooperation. However, China's territorial expansion in the South China Sea over recent years has not led to any concrete EU-Japanese policies directed at countering Beijing's unilateral territorial expansionism. Indeed, Brussels continued to remain very reluctant to get involved in Asian territorial disputes beyond statements urging all involved parties to solve disputes peacefully. Furthermore, it must not be forgotten that the EU's External Action Service (EEAS) is not an organization operating independently from EU member states, some of which have strong reservations about getting involved in disputes with China due to their close business and economic ties with China. Furthermore, the EU continues to insist that it is not taking sides in territorial disputes, and it probably does not unlike the U.S. - have the resources and capabilities in the region (i.e. troops and navy vessels) to deter China from building facilities and military bases on disputed islands in the South China Sea. The more Beijing seeks to unilaterally change the maritime territorial status quo in Asia in its favour, the more the EU and Japan should realize that consulting, let alone cooperating, with China on regional security is an illusion that takes place on paper and paper only. Indeed, China's increasingly aggressive regional policies and policies related to territorial claims in Asia should, from Tokyo's perspective, inject a 'sense of urgency' into European interest in Asian regional security and encour- 
age European policymakers to side with Japan in its efforts to keep China's regional territorial expansionism in the East and South China Seas in check.

Regardless of whether or not the bilateral EU-Chinese dialogue on Asian security produces tangible results, this dialogue has, in the past in Japan-the EU's supposed 'natural ally' in Asian politics and security - led to the perception that Brussels is not the kind of security policy partner willing to support Tokyo's China security policies aimed at deterring Beijing's territorial ambitions toward Japanese-controlled maritime areas in the East China Sea. In fact, given the currently tense Japanese-Chinese relations, the EU discussing Asian security with Beijing without strongly condemning Chinese violations of Japanese territorial sovereignty in waters around the Senkaku Islands is a de facto confirmation to some Japanese policymakers and scholars that the reality of EU-Japan security cooperation does not live up to the above-mentioned term 'natural ally' in Asian politics and security. In other words, one could conclude that from Tokyo's perspective, the $\mathrm{EU}$, as regards Asian security of direct and vital interest to Japan, is reliable and credible only within limits unless and until Brussels unambiguously sides with Tokyo on its policies related to the defence of Japanese-controlled territory in the East China Sea. To be sure, Tokyo is probably very aware that, judging by Beijing's insistence on its sacred 'principle of non-interference' on a come-what-may-basis, Brussels openly and on the record criticizing Chinese violations of Japanese-controlled territorial waters around the Senkaku Islands (Beijing refers to them as Diaoyu Islands) in the East China Sea, would probably interrupt (if not indefinitely terminate) the EU-China bilateral dialogue on Asian security. However, this should, from Japan's perspective, not stand in the way of Brussels supporting Tokyo's policies that oppose what Tokyo refers to as unlawful and aggressive Chinese intrusions into Japanese-controlled territorial waters in the East China Sea. However, because the EU - like the US for that matter - officially takes a neutral stance on sovereignty in Asian territorial disputes, Brussels will most probably continue to exercise restraint, and avoid siding with Japan too openly and publicly on the Senkaku/Diaoyu Islands dispute. Then again, the author's numerous off the official record conversations with EU policymakers have confirmed that Chinese policies related to territorial claims in the East and 
South Chinas are indeed perceived as aggressive and very counterproductive to Asian political and security stability.

To be sure, Tokyo policymakers are aware of the limits of the EU's ability and preparedness to voice unambiguous and outspoken support for Japanese policies related to Chinese territorial claims in the East China Sea, and against that background even the EU's 'timid' calls towards Beijing to solve territorial disputes peacefully are probably appreciated all the same in Tokyo. Regarding concrete and sustainable support for Tokyo's policies related to the defence of Japanese territories in the East China Sea, Washington is, and will continue to remain, Tokyo's most important partner. Washington has, over the last two years more than once confirmed that it is - due to its obligation under Article V of the US-Japan Security Treaty prepared to defend territory under Japan's administration, prepared — to jointly defend the Senkaku Islands with Japan in the case of a Chinese attempt to invade and occupy the islands. Consequently, support from the EU for Asian countries disputing territories with Beijing in the East and South China Seas are helpful and positive as such, but such support does not in any way equal Washington's very concrete support, and the US ability to actually and physically deter Chinese vessels from intruding into maritime areas controlled by other countries, be in the East or South China Sea. While Tokyo is realistic about Brussels' self-imposed obligation to take - least for now - a (very) cautious position on Chinese intrusions into Japanese-controlled territorial waters in the East China Sea, joint EU-Chinese statements coming out of the bilateral security dialogue must nonetheless sound hollow to the ears of Japanese policymakers in view of Chinese attempts to challenge Tokyo's control over Japanesecontrolled territorial waters in the East China Sea (through illegal intrusions into disputed territorial waters).

\section{JOINTLY CHECKING ON CHINESE TERRITORIAL EXPANSIONISM?}

Japan, governed by the pro-defence LDP, led by Abe, undoubtedly questions the EU a security actor in Asia, able to help defend Japanese security interests in East Asia. While the above-mentioned bilateral defence relations with countries such as UK and France have been intensified over recent years, it is accurate to conclude that the EU 
as a hard security policy actor with a role and influence in Asian hardsecurity issues continues to have secondary importance in Tokyo's security policymaking circles. ${ }^{10}$ Chinese unilateral territorial expansionism in the East and South China Seas over recent years has led to Tokyo and Brussels voicing joint concerns about China claiming disputed territories in the South China Sea as part of China's sovereign territory. "We are concerned about the situation in the East and South China Seas, and emphasize the fundamental importance of peaceful management and settlement of disputes. We express our strong opposition to any intimidating, coercive or provocative unilateral actions that could alter the status quo and increase tensions, and urge all states to refrain from such actions as land reclamations including large scale ones, building of outposts, as well as their use for military purposes and to act in accordance with international law including the principles of freedoms of navigation and overflight" announced Brussels and Tokyo in Hiroshima in April 2016. ${ }^{11}$ Even if China is not explicitly mentioned in that statement, it is very clear that it is China's unilateral territorial expansionism that was meant when the statement speaks of 'provocative unilateral actions.' However, such a statement has not been followed-up on by joint EU-Japan policies aimed at deterring China from unilaterally expanding its territories in the South China Sea. Over the last two years many papers and policy briefs were written, in which it was argued that China's military rise and its very assertive, and indeed aggressive, policies related to territorial claims in the East and South Chinas 'could', or indeed 'should', lead to increased EU-Japan hard security cooperation. That, however, did not happen, even though some EU members (e.g. France during the IISS Shangri-La Dialogue in Singapore in 2016) called on fellow European countries to consider coordinated EU patrolling activities in the South China Sea. ${ }^{12}$ However,

10 E. Pejsova, The EU and Japan: Stepping up the Game; Brief Issue 15/2015; European Union Institute for Security Studies (EUISS) Paris. Available from: http://www.iss.europa.eu/uploads/media/Brief_15_EU-Japan.pdf.

11 European External Action Service (EEAS) (2016 April 11) G7 Foreign Ministers' Statement on Maritime Security April 11, 2016 Hiroshima, Japan; http://eeas.europa.eu/statements-eeas/2016/160411_05_en.htm.

12 D. Roman, France to Push for Coordinated EU Patrols in South China Sea. Bloomberg News june 5, 2016; http://www.bloomberg.com/news/articles/2016-0605/france-to-push-for-coordinated-eu-patrols-in-south-china-sea. 
suggesting such joint patrol activities is one thing, doing the patrolling quite another, and it remains very unlikely that there will be coordinated European patrolling activities in the South China Sea anytime soon. Then again, should China continue to unilaterally reclaim disputed territories and render the passage of vessels through international waters in the South China Sea difficult in the months and years ahead, it cannot be excluded that Europe, together with the U.S., and Japan, would initiate coordinated patrolling in the South China Sea.

Chinese current policies related to territorial claims in the South China Sea are objectively aggressive, de facto obliging outside actors like Europe and more importantly the U.S. - in view of economic and business interests in the region - to defend themselves against the consequences of Chinese unilateral territorial expansionism. Hiroshima in 2016 was not the first time that Brussels and Tokyo expressed joint opposition to Chinese territorial expansionism. "We continue to observe the situation in the East and South China Seas and are concerned by any unilateral actions that change the status quo and increase tensions. We support the full and effective implementation of the 2002 Declaration on the Conduct of Parties in the South China Sea and the rapid conclusion of the negotiations to establish an effective Code of Conduct in the South China Sea. We highlight the constructive role of practical confidence-building measures, such as the establishment of direct links of communication in cases of crisis and crisis management mechanisms in this regard". ${ }^{13}$

While such a joint statement is positive per se and can be understood as Brussels and Tokyo jointly expressing opposition against Chinese unilateral territorial expansionism, it certainly could have gone beyond 'highlighting the constructive role of confidence-building measures' if the purpose was to send a clear message that Brussels and Tokyo are prepared to be more than just 'concerned' about Chinese aggressive policies related to (largely illegitimate) territorial claims in the South China Sea. Instead, the declaration could/should have called

13 European Commission, Fact Sheet-23rd Japan-EU Summit, Tokyo, 29 May

2015 Joint Press Statement; http://europa.eu/rapid/press-release_MEMO-155075_en.htm. 
on China directly and unambiguously to stick to what it has promised to do in the past: only talk and negotiate on territorial disputes it has with other Southeast Asian nations as opposed talking while at the same building civilian and military facilities on disputed islands. Instead, Beijing is, through the construction of civilian and military facilities on disputed islands, rapidly and continuously creating facts on the ground, and a timid and very diplomatic EU-Japan joint statement is obviously not changing anything about that. To be sure, a stronger EU-Japan statement in 2016 and a statement, which would have directly called on China to not unilaterally change the territorial status quo in the region would not have changed anything about Beijing's territorial expansionism either, but at least Beijing would have received a clearer message, to which it could have reacted on (as opposed to ignoring the above-mentioned statement). The statement is indeed rather toothless and to the outside analyst, it looks more like a statement for the sake of making a statement as opposed to a strong statement that is really expected to have an impact on Chinese regional policy behaviour.

Japan's constitutional reinterpretation in 2014, and the adoption of new national security laws have also been accompanied by debates on whether Tokyo's naval vessels could, or should, against the backdrop of Chinese territorial expansionism in the East and South China Seas, join U.S. Freedom of Navigation Operations (FONOPs) in the South China Sea. While the US currently conducts FONOPs in the South China Sea alone, in June 2015 Japanese Admiral Katsutoshi Kawano, Chief of the Joint Staff of Japan's SDF, declared that the MSDF could consider conducting joint patrols with the US Navy 'depending on the situation'. ${ }^{14}$

The U.S. is currently on its own conducting FONOPs in the South China Sea, and while it cannot be completely excluded that navies from other countries can in the future join the U.S. Navy patrols in the South China Sea, it seems unlikely tha this will happen

14 See F. Gady, Japan's Top Military Officer: Joint US-Japanese Patrols in South China Sea a Possibility. The Diplomat June 26, 2015; http://thediplomat.com/2015/06/ japans-top-military-officer-joint-u-s-japanese-patrols-in-south-china-sea-a-possibility/. 
any time soon. To be sure, jointly patrolling the South China Sea with the U.S. Navy could be easier said than done, as Tokyo would have to adopt laws, which authorize its navy to conduct such operations. Indeed, Japan's constitutional re-interpretation of 2014 and the 2015 national security laws do not explicitly authorize Japan's navy to jointly conduct FONOPs with the U.S. and such patrols would indeed be very controversial. In fact they could be unconstitutional and in violation of war-renouncing Article 9 of the Japanese constitution. Adopting laws to enable Japan's navy to jointly patrol Asian territorial waters, however, is not the only obstacle Tokyo would have to overcome. The limits of Japanese naval capacities too are an issue in view of the fact that the country's naval and coast guard vessels are already engaged in patrolling Japanese territorial waters close (e.g. in the East China Sea around the Japanese-controlled Senkaku Islands) from the Japanese mainland. With regard to the East China Sea, Beijing is clearly very worried about Tokyo authorizing its military to execute the aforementioned right to collective self-defence, as Japan's SDF, together with the country's very well-equipped and state-of-the art coast guard, are authorized to defend US military units when jointly defending Japanese-controlled islands in the East China Sea, against, for example, Chinese attempts to 're-conquer' or occupy the Japanesecontrolled, but contested, Senkaku Islands; Beijing calls these islands Diaoyutai, claiming sovereignty over them. China has, through its intrusions into Japanese-controlled territorial waters around the Senkaku Islands, sought to challenge and disrupt effective Japanese control over the islands the territorial waters surrounding them. Paul O'Shea argues that this Chinese tactic is part of what he calls the 'sovereignty game'. ${ }^{15}$ To be sure, the author's numerous conversations and interviews with Chinese scholars and policymakers leave little doubt that the islands are part of sovereign Chinese territory as far as Beijing is concerned. Given, however, that the islands and the waters around them are controlled by Tokyo, Beijing, at least for now, will most probably continue to limit itself to challenging Tokyo's control through

15 P. Shea O', Sovereignty and the Senkaku/Diaoyu Dispute; Working Paper 240, European Institute of Japanese Studies, Stockholm School of Economics 2012; http://www.academia.edu/3445337/Sovereignty_and_the_Senkaku_Diaoyu_Territorial_ Dispute. 
occasional intrusions. For Europe there would certainly be repercussions for its ties with China in the case of joint patrolling in the South China Sea, as Beijing is clearly acting in zero-sum terms in this context, and hence EU-Japan military security cooperation would almost inevitably lead to the interruption of the so-called EU-China HighLevel Strategic Dialogue. However, in realpolitik terms that should not be of great concern to EU policymakers, for at least two reasons. The EU-China High-Level Strategic Dialogue has not produced any Chinese willingness to let the EU 'interfere' in China's regional and global security policies. In other words, the part of the bilateral dialogue that deals with security issues is arguably nothing more than 'window-dressing', as opposed to a dialogue that produces actual results, even if Brussels, in official declarations, claims that China is prepared to take European advice regarding Chinese security policies into account. Consequently, Beijing interrupting bilateral consultations on Asian security with Brussels is not something EU policymakers should loose much sleep over, as Beijing never intended to include the EU in its security policy making in the first place. In fact, over the years the opposite has been the case. Every time the EU and individual EU member states have criticized China's regional foreign and security polices, be it Chinese territorial expansionism in the South China Sea, its policies towards Taiwan, its interference in Hong Kong's domestic affairs, such as the unlawful abduction of Hong Kong citizens to Mainland China, Beijing has reacted by reminding Brussels not to interfere in China's 'internal affairs.' Indeed, many Chinese scholars the author interacted with over recent years have charged themselves with the task of very assertively defending the official Chinese positions on Taiwan, Hong Kong and Chinese policies related to territorial claims in the East and South China Seas. More often not than not this has been an obstacle to constructive academic exchanges (as opposed to Chinese scholars repeating the official government positions) and the author is by far not the only scholar who has experienced such behaviour and interactions when interacting with Chinese scholars. Second, as Brussels has repeatedly stated over many years, it is Tokyo, and not Beijing, which is the EU's 'natural ally' in Asian security. Expanding bilateral cooperation with Tokyo is what really should matter to policymakers in Brussels. The fact that political rhetoric on the EU-Japan 'natural alliance' has yet to catch up with political reality is another matter. 


\section{CONCLUSIONS}

Intensifying EU-Japanese cooperation, the Japanese scholar Michito Tsuruoka argues, requires both Japan and the EU to overcome what he calls the 'expectations deficit' in EU-Japan relations. ${ }^{16}$ Today, it is probably fair to conclude that such an 'expectations deficit' (if it ever existed), has been overcome after years of joint experience in non-military security cooperation. 'Overcome' in the sense that both Brussels and Tokyo understand what they can and cannot expect from each other in terms of commitment and resources invested into non-military security cooperation on the ground. While the official rhetoric seems to suggest the SPA will further intensify bilateral security cooperation, it remains to be seen how and in which areas such cooperation could be intensified in the years ahead. Brussels and Tokyo have yet, after years of mentioning or indeed promising such a legal basis to adopt the above-mentioned legal framework to enable sustainable Japanese contributions to EU CSDP missions. While the reasons for that are undoubtedly complex from legal and procedural perspectives, the fact that the legal framework has been discussed for years without having been adopted, points to a lack of urgency to institutionalize Japanese contributions to European CSDP missions. Tokyo under Abe is, for the reasons cited above, seemingly more interested in maintaining and indeed intensifying hard security cooperation with Washington under Trump, as opposed to intensifying soft security cooperation with Europe.

The above-mentioned Chinese territorial expansionism will, in the near future, most probably not lead to more EU involvement in Asian hard security through the above-mentioned maritime patrolling, either alone, or jointly with Japan. However, if Japan decided to start patrolling in the South China Sea, and as mentioned above, there are indications that Japanese defence planners are at least considering the possibility of maritime patrolling in the South China Sea, it is advisable that the EU and individual member states do not a priori exclude the

16 M. Tsuruoka, The EU and Japan: Making the Most of Each Other. European Union Institute for Security Studies (EUISS) 2013; http://www.iss.europa.eu/publications/detail/article/the-eu-and-japan-making-the-most-of-each-other/. 
possibility of joining such patrolling activities in view of their economic and political interests in the region. Japan patrolling the South China Sea is, however, as mentioned above, from a constitutional perspective not uncontroversial and could even be a violation of war-renouncing Article 9 of the Japanese constitution. However, in view of equivocating EU reactions to the above-mentioned French proposal for joint European patrolling in the South China Sea, it remains very unlikely that there will be active consideration of coordinated European patrolling activities in the South China Sea anytime soon. From a strategic point of view, however, EU policymakers were probably ill advised to categorically exclude the possibility of joint European patrolling in the South China Sea. From a legal and operational point of view, there is nothing preventing the EU and European member states from jointly patrolling international waters in the South China. Brussels excluding, at least for now, any consideration of such a possibility does not necessarily add to the credibility of the EU as global foreign and security policy actor.

The arrival of Donald Trump in the White House has not resulted in the Abe administration developing a sense of urgency to rapidly adopt the SPA with the EU as a counterweight to potentially illiberal, aggressive, isolationist or interventionist U.S. policies in Asia. In fact, the opposite, at least it seems for now, has turned out to be the case. As elaborated above, Abe lost no time in presenting himself as reliable and, at least in the eyes of a critical outside observer, as an obedient U.S. ally in East Asia. To be sure, Abe will not stay in power forever, and the kind of security and defence policies he is pursuing could, in the years ahead, be replaced with policies more favourable to the kind of cooperation the SPA with the EU envisions.

Japan's solidarity with the U.S. and the EU in 2014 in imposing economic sanctions in reaction to Russia's illegal annexation of Crimea was an important indication of Tokyo's preparedness to support

17 S. Raine S., A. Small, Waking Up to Geopolitics. A New Trajectory of EUJapan Relations. The German Marshall Fund of the United States (GMF) Washington 2015; http://www.gmfus.org/publications/waking-geopolitics-new-trajectory-japaneurope-relations. 
Western policies aimed at safeguarding international legal norms. ${ }^{17}$ By imposing sanctions on Russia, Japan had back then taken a clear position and is without doubt counting on European countries' support for its efforts to deter Chinese territorial ambitions in the East and South China Seas. Indeed, Japan is expecting more European support for Tokyo's defence of its territorial integrity in the East China Sea in the face of Chinese intrusions into Japanese-controlled territorial waters. As mentioned above however, the EU remains - at least for now - reluctant to offer Japan support that goes beyond the kind of verbal support Brussels is providing Tokyo with. It is advisable for the EU and Japan to act to safeguard their individual and joint credibility, and to choose clearly whether or not to strictly limit bilateral cooperation to non-military modalities, which would exclude joint patrolling activities in the South China Sea, or whether to respond to a more unstable security environment by commencing joint military security cooperation in East and Southeast Asia. Regarding joint capacity-building assistance, some policy experts suggest that the EU, NATO, and Japan could pool resources and consider trilateral security cooperation. However, this has been suggested several times in the past, and expanding bilateral to trilateral cooperation probably does not necessarily contribute to making EU-Japan cooperation less complicated and more efficient. 'Pooling resources' is more easily said than done in international relations. All of this points to the conclusion that the SPA, if and when finally adopted, could indeed not turn out to be the 'big bang' of EUJapan cooperation in regional and global politics and security, but will rather provide existing and future cooperation little more than an institutional framework. 
